\title{
ФОРМУВАННЯ МЕХАНІЗМУ РЕАЛІЗАЦІЇ ІНВЕСТИЦІЙНОÏ СТРАТЕГІЇ РОЗВИТКУ АГРОСФЕРИ РЕГІОНУ
}

\author{
Турленко Наталія Володимирівна \\ кандидат економічних наук, докторант \\ Одеська національна академія харчових технологій (м. Одеса, Україна) \\ ORCID 0000-0001-6826-8546 \\ volodymyr@wiktoriya.com
}

В статті досліджуються основні складові процесу формування механізму реалізації інвестиційної стратегії розвитку агросфрери регіону. Обгрунтовано структуру механізму реалізації інвестиційної стратегії розвитку агроссрери регіону. Викладено аспекти методики аналізу й оцінювання рівня ризику інвестиційних проектів аграрних підприємств регіону. Визначено проблеми використання сучасних механізмів та інструментів стратегічного управління у агроссфері регіону.

Ключові слова: механізм реалізації, агросфрера регіону, розвиток регіону, інвестиційна стратегія, інвестування.

DOI: https://doi.org/10.32845/bsnau.2019.4.14

Постановка проблеми у загальному вигляді та їі зв'язок із важливими науковими чи практичними завданнями. Однією з найбільш важливих функцій державного регулювання в розвиткові сільських територій є розробка стратегії соціально-економічного розвитку регіону, яка є базисом підвищення конкурентних переваг території й господарства регіону. Особливо це важливо для розвитку основних галузей сільських територій, де найважливіше місце відводиться агросфері. Але для реалізації будь-яких планів та стратегічних рішень необхідно мати відповідні інвестиційні можливості. Тому дослідження саме програм інвестиційної стратегії розвитку агросфрери регіону і особливостей формування механізму її реалізації $є$ актуальним і потребує окремого дослідження.

Аналіз останніх досліджень і публікацій, в яких започатковано розв'язання даної проблеми i на які спирається автор, виділення невирішених раніше частин загальної проблеми, котрим присвячується означена стаття. Дослідження аспектів теорії та практики інвестицій, інвестиційної діяльності, що мають важливе значення для визначення пріоритетних напрямів в аграрному секторі та агробізнесі, досліджували як зарубіжні вчені Колеман Д., Фуллер Б., Херстейн Р., Джоргенсон Д., Креллє В., Лернер Д., Мегінсон, так і вічизняні І. О. Бланк, В.П.Горьовий, С. О. Гуткевич, А. А. Задоя, О. В. Захарчук, М. І. Кісіль, М. Ю. Коденська, М. М. Кропивко, В.В. Лагодієнко, І. І. Лукінов, Р.П. Мудрак, Г. М. Підлісецький, П. Т. Саблук, А.М. Ужва, П. І. Юхименко, та інші. Водночас, питання формування механізму реалізації інвестиційної стратегії розвитку агроссеери регіону потребують подальшого вивчення та обгрунтування.

Формулювання цілей статті (постановка завдання). Метою статті $є$ дослідження підходів до формування механізму реалізації інвестиційної стратегії розвитку агросфери регіону. У межах досягнення мети окреслено наступні завдання: дослідити методику аналізу й оцінювання рівня ризику інвестиційних проектів аграрних підприємств регіону, обгрунтувати структуру механізму реалізації інвестиційної стратегії розвитку агросфрери регіону, визначити проблеми використання сучасних механізмів та інструментів стратегічного управління у агросффері регіону.

Виклад основного матеріалу дослідження 3 повним обґрунтуванням отриманих наукових результатів. У процесі розробки інвестиційної стратегії агросфери регіону необхідно встановити критерії для оцінки й відбору інвести-

ційних пропозицій аграрних підприємств. Вказані критерії повинні відповідати формованій системі управління інвестиційними й фінансовими ризиками реалізації проектів.

Існує багато показників фінансово-економічної стабільності та інвестиційної привабливості проектів, що викликає певні труднощі при оцінці проектних рішень й ризиків. Виникає необхідність розробки інтегрального показника оцінки фінансово-економічної стабільності [1].

Інвестування коштів у проекти аграрних підприємств у різних формах пов'язано із факторами невизначеності й ризиками, основними з яких $є$ так звані «проектні ризики» - ризики реалізації реальних інвестиційних проектів аграрних підприємств. Серед показників оцінки проектних рішень рівень проектного ризику займає вагоме місце, поряд із показниками обсягу інвестованих коштів й чистим дисконтованим прибутком.

Під проектним ризиком стосовно реального інвестиційного проекту аграрного підприємства слід розуміти можливість (ймовірність) виникнення у процесі його втілення несприятливих (ризикових) подій, які можуть негативно вплинути на його ефективність, привести до зниження доходів та виникнення непередбачуваних витрат. Рівень ризику інвестиційного проекту, навіть типового для конкретного підприємства, $є$ диференційованим. Кожен проект знаходиться під впливом індивідуально властивої йому системи численних об'єктивних і суб'єктивних динамічно змінних фракторів. Кожен інвестиційний проект потребує індивідуального аналізу й оцінювання складу й рівня ризику у сформованих умовах його реалізації [2].

Методика аналізу й оцінювання рівня ризику інвестиційних проектів аграрних підприємств повинно грунтутватися на таких принципах й підходах:

- узагальнена оцінка ризику проекту повинна здійснюється на основі інтегрального показника рівня проектного ризику;

- базисом аналізу й оцінки рівня ризику інвестиційного проекту є оцінювання ймовірного діапазону відхилень показників ефективності інвестиційного проекту від їх рівня, закладеного у базовий варіант проекту;

- при оцінці ризику проекту можна й доцільно використовувати широкий діапазон показників ефективності;

- для кількісної оцінки величини ймовірних відхилень показників ефеективності інвестиційного проекту від базової величини слід використовувати показники, що характеризують коливання; 
- оцінку можливого рівня коливань показників ефективності інвестиційного проекту слід здійснювати з максимальним урахуванням можливих змін умов його практичного втілення.

На вказаних методичних засадах можливо сфрормувати оціночний інструментарій для аналізу ризиків конкретних інвестиційних проектів аграрних виробників. Ключовими методами, які набули найбільш широкого розповсюдження при аналізі проектних рішень, є метод «дерево рішень», який використовується для аналізу «чутливості» інвестиційного проекту й метод імітаційного моделювання - використовується для сценарного аналізу інвестиційного проекту.

Вказаний аналітичний підхід на аграрному підприємстві головним чином підходить для цілей комплексного аналізу й оцінки впливу ключових факторів на показники ефективності інвестиційного проекту підприємства за різних ймовірних сценаріїв його практичної реалізації - від оптимістичного до песимістичного. При здійсненні аналізу моделювання зміни факторних ознак інвестиційного проекту повинно здійснюватися із урахуванням їх взаємозв'язків та взаємозалежності.
Для кожного можливого сценарію (реалістичний, оптимістичний, песимістичний) необхідно визначити ймовірність реалізації.

Для оцінки ймовірних коливань показників економічної ефективності інвестиційного проекту за різних сценаріїв реалізації слід визначати статистичні показники відхилення та варіації, які дають змогу оцінити рівень ризику проекту. Високе значення відхилення й варіації свідчить про високий рівень ризику проекту. Для здійснення сценарного аналізу найбільш доцільно використовувати показники чистого приведеного доходу та внутрішньої норми доходності [3].

За результатами розрахунків очікуваного чистого приведеного доходу та внутрішньої норми доходності та показників їх варіації можна зробити порівняння альтернативних проектів та висновки про ефективність та доцільність вибору проекту для інвестування, що є важливішим завданням для реалізації інвестиційної стратегії агросфери регіону.

Загальна схема механізму реалізації інвестиційної стратегії аграрної сфрери регіону відображає його багаторівневу структуру та систему програмних дій (рис. 1).

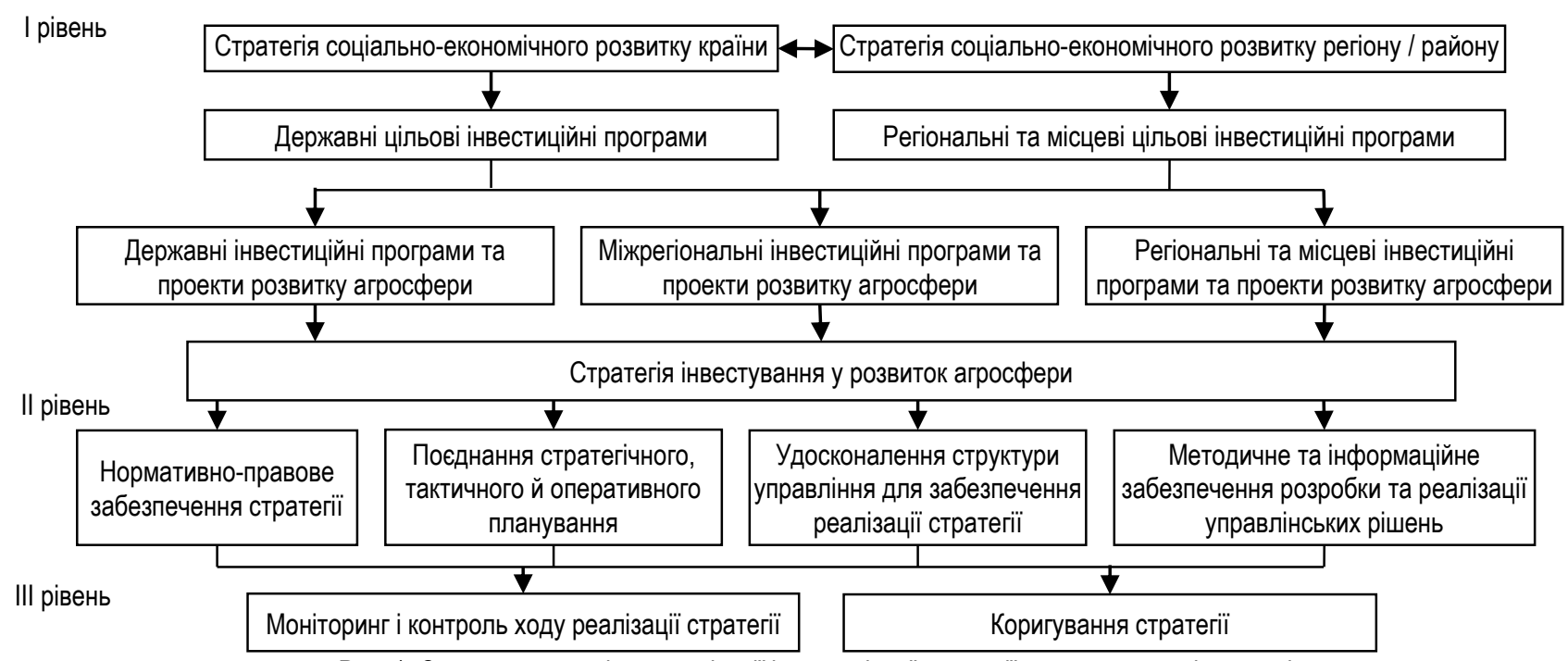

Рис. 1. Структура механізму реалізації інвестиційної стратегії розвитку агросфери регіону

Досвід регіонального стратегічного планування розвитку агросфрери свідчить, що новітні інструменти й механізми управління мало впроваджуються у систему керування процесами розвитку аграрної сфери. Основні проблеми стратегічного управління розвитком агросфери на регіональному рівні наведені у табл. 1.

Таблиця 1

Проблеми використання сучасних механізмів та інструментів стратегічного управління у агросфері регіону

\begin{tabular}{|c|c|}
\hline Проблема & аслідки \\
\hline $\begin{array}{l}\text { 1. низький рівень впровадження } \\
\text { механізмів та інструментів бюджетування, } \\
\text { орієнтованого на результат }\end{array}$ & $\begin{array}{l}\text { Механізми бюджетування, орієнтованого на результат в основному зосереджені на } \\
\text { загальнодержавному рівні управління, що ускладнює аналіз та оцінку якості регулювання } \\
\text { розвитку агросфери на регіональному рівні, порушує взаємозв'язок дій загальнодержавних } \\
\text { й регіональних структур регулювання розвитку агросфери }\end{array}$ \\
\hline $\begin{array}{l}\text { 2. Відсутність механізмів та інструментів } \\
\text { узгодження й координації стратегій } \\
\text { розвитку агроссрери регіонів та районів }\end{array}$ & $\begin{array}{l}\text { Неможливість ефективної міжрегіональної кооперації, низька результативність } \\
\text { використання бюджетних ресурсів для реалізації державних і регіональних програм } \\
\text { аграрного розвитку }\end{array}$ \\
\hline $\begin{array}{l}\text { 3. Відсутність чітко визначеної стратегії } \\
\text { територіального розвитку країни }\end{array}$ & $\begin{array}{l}\text { Розпливчатість та неузгодженість державних й регіональних пріоритетів розвитку територій, } \\
\text { що уповільнює вирішення соціально-економічних питань розвитку сільських територій }\end{array}$ \\
\hline $\begin{array}{l}\text { 4. Відсутність координації та синхронізації } \\
\text { регіональних інфраструктурних проектів } \\
\text { (у сферах транспорту, енергопостачання, } \\
\text { комунального господарства тощо) }\end{array}$ & $\begin{array}{l}\text { Складність забезпечити планомірну реалізацію інвестиційних програм й проектів розвитку } \\
\text { села та аграрного виробництва на рівні регіону }\end{array}$ \\
\hline $\begin{array}{l}\text { 5. Відсутність досвіду й культури } \\
\text { стратегічного планування }\end{array}$ & $\begin{array}{l}\text { Неможливість належного фахового підходу до розробки регіональних галузевих стратегій } \\
\text { розвитку агросфери, що веде до недоліків стратегічних планів, порушень термінів та змісту } \\
\text { запланованих робіт. }\end{array}$ \\
\hline
\end{tabular}


Удосконалення механізму формування та реалізації стратегії розвитку агросфери регіону передбачає ряд напрямків:

І. Удосконалення управління розвитком агроссрери.

Регулювання діяльності бізнес-суб'єктів агросфери здійснюють як галузеві органи влади, так і органи влади регіону, на які покладено відповідальність за соціально-економічний розвиток території. При цьому часто виникають конфлікти інтересів розвитку сусідніх регіонів, та не враховується весь комплекс інтересів аграрного виробництва та сільських територій. Отже, необхідний чіткий розподіл повноважень й відповідальності між органами державної влади регіону та галузевими органами регулювання агросфери.

Органи регулювання розвитку агросфрери мають впливати на бізнес-суб'єкти та структуру агросфери регіону за такими основними напрямками:

- аналіз й оцінка кількісних та якісних параметрів державних закупівель агропродовольчої продукції;

- маркетингове інформаційне забезпечення аграрних підприємств щодо стану агропродовольчих й ресурсних ринків у територіальному та продуктовому вимірах;

- стимулювання інноваційного процесу, економічні стимули впровадження досягнень науки і техніки у аграрне виробництво;

- розробка стандартів й сучасних техніко-економічних норм, що забезпечують безпеку й екологічність аграрного виробництва;

- податкова, митно-тарифна політика, регулювання тарифів на ресурси для бізнес-суб'єктів із метою активізації розвитку агросфери.

II. Удосконалювання нормативно-правового забезпечення формування та реалізації стратегії розвитку агросфрери регіону.

Законодавством не повною мірою врегульовані питання взаємозв'язку державного та регіонального рівнів стратегічного планування соціально-економічного розвитку галузей та регіонів. Недосконалість інструментів та механізмів регулювання соціально-економічного розвитку регіонів на загальнодержавному рівні спричиняє недостатню обґрунтованість розподілу ресурсів на фінансування інвестиційних програм і проектів. Необхідні нові підходи до координації різних рівнів державного регулювання розвитку агросфери та сільських територій.

Нормативно-правове забезпечення стратегічного планування розвитку агросфери та села повинне забезпечити ефективну регіональну аграрну політику, встановити базові принципи територіального розташування об'єктів виробничої та соціальної інфраструктури села, чітко визначити цілі, завдання й ключові напрямки секторального та територіального розвитку агросфери, із урахуванням диспропорцій у розвитку регіонів та їх специфічних особливостей.

Удосконалення нормативної бази розвитку агросфери регіону доцільно здійснювати за такими напрямками:

- варіювання ставок податків у залежності від сфери діяльності та напрямків витрачання грошових та інших ресурсів;

- гнучкий підхід до встановлення структури надходжень від оподаткування до бюджетів різного рівня. Ц дасть змогу враховувати особливості господарювання в кожному регіоні й можливості суб'єктів агробізнесу, а також сприяти активності органів державної влади регіону й органів місцевого самоврядування у напрямку розширення бази оподаткування;

- запровадження адаптивної моделі фінансування регіональних цільових програм розвитку агросфери й міжбюджетних відносин у цьому процесі. На районному та місцевому рівнях важливим питанням $€$ узгодження стратегії із стратегіями вищого рівня.

Завдання удосконалювання механізму стратегічного управління розвитком агросфери регіону визначає необхідність внесення коректив у методи стратегічного планування у цій галузі та її секторах. Перед фрінансовими органами постає питання про оцінку доцільності та ефективності вкладення коштів у агроссреру з точки зору суми та строків інвестування, характеристик конкретного сектору та проекту. Органи влади регіону, місцевого самоврядування та аграрні підприємства вирішують питання як узгодження інструментів, механізмів й циклів стратегічного та бюджетного планування [4].

Для вирішення цього питання доцільно, виходячи з стратегічних настанов, визначати цілі розвитку агроссрери, цільові показники та на їх основі формувати програми розвитку. Це дозволить вирішити завдання інтеграції стратегії й бюджету розвитку, виявляти та відхиляти інвестиційні заявки, які не $€$ непріоритетними.

Важливість удосконалювання інформаційно-методичного інструментарію формування та реалізації інвестиційної стратегії розвитку агросфрери регіону визначається тим, що існуючі ресурси (зокрема органи державної статистики) не дають змогу здійснити адекватну оцінку потенціалу розвитку агроссрери та обґрунтувати стратегічні напрямки розвитку аграрного виробництва та сільських територій регіону. Необхідне створення у агросфері регіону інформаційно-методичної бази, яка дасть змогу ідентифікувати проблеми ії розвитку, винаходити варіанти їх вирішення та поширювати цей позитивний досвід. Ключову роль тут повинні відігравати аналіз та оцінка можливостей та ресурсів розвитку агросфери регіону, реструктуризації господарського комплексу агросфери, резервів підвищення ефективності аграрного виробництва, можливостей покращення кадрового забезпечення, спроможності органів влади до забезпечення інноваційного розвитку галузі та території.

Необхідне систематичне статистичне дослідження стану сільських територій, що дасть змогу оцінити потенціал інвестиційної інфраструктури і можливості реалізації проектів у існуючих умовах, виявляти існуючі проблеми та бар'єри для розвитку агробізнесу, визначати напрямки й види підтримки 3 боку держави. Такі статистичні дослідження повинні ґрунтуватися на єдиному методичному базисі, що дозволить робити міжрегіональні порівняння, та бути постійно доступними органам влади та місцевого самоврядування для прийняття стратегічних та оперативних рішень.

Визначення та обґрунтування стратегічних напрямків розвитку агроссрери регіону повинне здійснюватися на принципах: цільової орієнтованості, комплексності та системності, диференціації та адаптивності, балансу ефрективності й ризику, балансу бізнесових, суспільних та владних інтересів, законності.

Розроблений варіант стратегії повинен забезпечувати виконання таких завдань:

- дотримання вимог продовольчої безпеки держави та регіону;

- забезпечення встановленого рівня і якості життя 
сільського населення;

- досягнення стратегічних цілей розвитку агросфрери із оптимальним рівнем витрат;

- ефрективне управління ризиками (виробничими, інвестиційними, фінансовими, ринковими та ін.);

- забезпечення прогресивного розвитку агросфрери регіону та підвищення ії конкурентоспроможності та міжнародних ринках.

Необхідне також формування дієвих механізмів узгодження різнорівневих та різнотериторіальних стратегій розвитку агросфрери. Нинішні підходи до узгодження стратегій різних регіонів мають певні недоліки:

- відсутність міжрегіонального співробітництва у формуванні стратегій та координації їх реалізації, що веде до неузгодженості стратегічних планів розвитку сусідніх регіонів, складності реалізації міжрегіональних інвестиційних проектів;

- відсутність спадковості та взаємозв'язку між регіональними й загальнодержавними стратегіями, що веде до зниження ефективності стратегічного управління.

Для вирішення вказаних проблемних питань слід:

- запровадити єдину методику та порядок розробки й прийняття стратегічних планів й програм розвитку агросфери;

- забезпечити підтримку найбільш важливих регіональних програм і проектів у рамках стратегічних пріоритетів розвитку агросфери;
- розробити чіткі протоколи взаємодії державних та регіональних органів влади і місцевого самоврядування у процесі розробки і затвердження програм і стратегій розвитку агросфери.

Завершальним етапом формування механізму реалізації стратегії розвитку агросфрери регіону є коригування та узгодження інвестиційно-фінансових і податкових інструментів її реалізації.

Висновки 3 даного дослідження і перспективи подальших розвідок у даному напрямку. Раціональним шляхом вирішенням завдання фрінансування інвестиційних програм і проектів у рамках реалізації стратегії розвитку агросфери регіону є досягнення такого стану, коли реалізація заходів забезпечує утворення джерел мобілізації фінансових ресурсів для подальшого саморозвитку. Акумулюючи фінансові ресурс для інвестування, слід їх спрямовувати їх на пріоритетні інвестиційні об'єкти стратегічного характеру, які дають змогу докорінної зміни стану агроссрери та її поступальний розвиток у майбутньому. 3 цієї точки зору одним з найважливіших інструментів є державні та регіональні цільові програми, розроблені із урахуванням вимог їх взаємозв'язку, синергічної взаємодії різних рівнів управління та господарювання, раціонального використання ресурсів, необхідного інституційного та інфрраструктурного забезпечення інвестицій. Необхідно забезпечити повне фінансування цільових програм, закріпивши це у бюджетному процесі.

\section{Список використаної літератури:}

1. Горбатюк Л. М. Окремі аспекти класифікації інвестицій. Вісник Полтавської державної аграрної академії. 2010 . №2. C. 201-204.

2. Лагодієнко В.В. Реалізація інвестиційного забезпечення інноваційної діяльності у харчовій галузі. Бізнес-Навігатор. 2013. №2(31). C. 178-183.

3. Bondarenko S., Lagodienko V., Sedikova I., Kalaman O. Application of project analysis software in project management in the pre-investment phase. International Journal of Mechanical Engineering and Technology, Volume 9, Issue 13, December 2018, pp. 676-684.

4. Ruslan Mudrak, Iryna Nyzhnyk, Volodymyr Lagodiienko, Nataliia Lagodiienko Impact of Seasonal Production on the Dynamics of Prices for Meat and Dairy Products in Ukraine. TEM Journal. Volume 8, Issue 4, Pages 1159-1168, DOI: 10.18421/TEM8408, November 2019.

References
1. Gorbatiuk L.M. (2010) Okremi aspekty klasyfikatsiyi investytsiy [Some aspects of classification of investments]. Bulletin of the Poltava State Agrarian Academy, vol. №2. pp. 201-204.

2. Lagodiienko V.V. (2013) Realizatsiya investytsiynoho zabezpechennya innovatsiynoyi diyal'nosti u kharchoviy haluzi [lmplementation of investment support for innovation in the food industry]. Business Navigator, vol. 2 no 33 .pp. 178-183.

3. Bondarenko S., Lagodienko V., Sedikova I., Kalaman O. (2018) Application of project analysis software in project management in the pre-investment phase. International Journal of Mechanical Engineering and Technology, Volume 9, Issue 13, December 2018, pp. 676-684.

4. Ruslan Mudrak, Iryna Nyzhnyk, Volodymyr Lagodiienko, Nataliia Lagodiienko (2019) Impact of Seasonal Production on the Dynamics of Prices for Meat and Dairy Products in Ukraine. TEM Journal. Volume 8, Issue 4, Pages 1159-1168, DOI: 10.18421/TEM84-08

Turlenko N.V., PhD, doctoral student, Odesa national academy of food technologies (Odesa, Ukraine)

Formation of the mechanism of implementation of the investment strategy for the development of the region's agrosphere.

The article examines the main components of the process of forming the mechanism of implementation of the investment strategy for the development of the region's agrosphere. The structure of the mechanism of implementation of the investment strategy for the development of the region's agrosphere is substantiated. Aspects of the methodology of analysis and risk assessment of investment projects of agricultural enterprises of the region are outlined.

In the process of developing an investment strategy for the agrosphere of the region, it is necessary to establish criteria for the evaluation and selection of investment proposals of agricultural enterprises. These criteria should be consistent with the established system of investment and financial risk management of project implementation. Based on the calculation of the expected net present 
income and the internal rate of return and indicators of their variation, it is possible to make a comparison of alternative projects and conclusions about the efficiency and feasibility of choosing a project for investment, which is a more important task for the implementation of the investment strategy of the region's agrosphere.

The importance of improving the information and methodological tools for the formation and implementation of the investment strategy for the development of the agrosphere of the region is determined by the fact that existing resources do not allow to adequately assess the potential of development of the agrosphere and to justify the strategic directions of development of agricultural production and rural territories.

The rational way to solve the problem of financing investment programs and projects within the framework of the implementation of the regional agrosphere development strategy is to reach a state where the implementation of measures ensures the creation of sources of mobilization of financial resources for further self-development. Accumulating financial resources for investing, they should be directed to priority investment objects of strategic nature, which allow a radical change in the state of the agrosphere and its progressive development in the future. From this point of view, one of the most important tools is the national and regional targeted programs designed to meet the requirements of their interconnection, synergistic interaction of different levels of management and management, rational use of resources, the necessary institutional and infrastructure investment support. It is necessary to ensure that the targeted programs are fully funded, enshrining this in the budget process.

Key words: implementation mechanism, agrosphere of the region, development of the region, investment strategy, investment.

Дата надходження до редакції: 21.10.2019 р. 